\title{
Animal behaviour: lethal violence deep in the human lineage
}

Article

Accepted Version

Pagel, M. (2016) Animal behaviour: lethal violence deep in the human lineage. Nature, 538. pp. 180-181. ISSN 1476-4687 doi: https://doi.org/10.1038/nature19474 Available at https://centaur.reading.ac.uk/67361/

It is advisable to refer to the publisher's version if you intend to cite from the work. See Guidance on citing.

To link to this article DOI: http://dx.doi.org/10.1038/nature19474

Publisher: Springer Nature

All outputs in CentAUR are protected by Intellectual Property Rights law, including copyright law. Copyright and IPR is retained by the creators or other copyright holders. Terms and conditions for use of this material are defined in the End User Agreement.

\section{www.reading.ac.uk/centaur}

\section{CentAUR}

Central Archive at the University of Reading

Reading's research outputs online 


\title{
Lethal violence deep in the human lineage
}

\section{Researchers estimate that the incidence of human lethal violence at the origin of our species was about six-times higher than the average mammal, but about as violent as expected given our Great Ape ancestry.}

\author{
Mark Pagel
}

Are humans naturally violent as the $17^{\text {th }}$ century philosopher Thomas Hobbes thought ${ }^{1}$, with our condition in the state of nature being one of 'continuall feare, and danger of violent death", or, as Rousseau imagined a century later ${ }^{2}$, neither good nor bad but moulded by their environments?

Social scientists have long confronted this question by examining large numbers of individuals from a variety of circumstances and then trying to average out extraneous factors to see what's leftover. In a paper published in this issue, Gomez and colleagues ${ }^{3}$ adopt a different approach: they use phylogenetic comparative methods from evolutionary biology ${ }^{4}$ to reconstruct humans' most probable ancestral rates of lethal violence at the origin of our species roughly 160,000 to 200,000 years ago. They conclude that we were about as violent as expected from our Great Ape and Primate past.

One of Darwin's great insights was that all living things evolve by a process of descent with modification such that species give rise to daughter species that inherit many of their ancestors' traits. Comparative biologists can use the family trees or phylogenies that arise from this process to infer the history of biological evolution, including dating past events, and reconstructing probable ancestral features of species that lived hundreds of thousands to hundreds of millions of years ago.

Gomez and colleagues applied comparative statistical techniques to a phylogeny of the Mammals (Figure), which includes the Primates, the order of mammals comprising the monkeys, the Great Apes, and the lineage that leads to modern humans. They compiled information on more than four million deaths in 1024 mammal species drawn from 137 or $80 \%$ of mammalian families including mice, horses, bats, rabbits and monkeys. Information for humans came from 600 studies including Palaeolithic samples, New and Old World Neo- and Mesolithic sites, Bronze and Iron age samples and anthropological sources from the past few centuries.

The authors then calculated for each species, the proportion of deaths, out of all counted, attributable to violence from a member of the same species. Including only acts of within-species violence is important. Lions and tigers routinely - we would say it is in their nature - kill members of other species, but are less often lethally violent towards each other. Within-species violence therefore gets at what Hobbes and Rousseau disagreed about, and is interesting because members of the same species typically have all of the same weapons, making violence among them risky.

Using the values from contemporary species, the authors reconstructed the rate of lethal violence at the origin of mammals at about $0.30 \%$ or approximately 1 in 300. Rates of lethal violence then rise steadily throughout the Mammalian phylogeny (Figure) as the reconstructed ancestors draw closer to Primates and the Apes: the rate is $\sim 1.1 \%$ for the ancestor of primates, rodents and hares, $2.3 \%$ for the common ancestor of primates and tree shrews and roughly similar at $1.8 \%$ for the ancestor of the Great Apes. The increases in lethal violence coincide with species having increasing amounts of group living and territoriality: group living places individuals routinely in close contact, and territoriality means that groups might potentially compete over resources. Finally, Gomez et al. reconstruct the incidence of human lethal violence at the origin of our species at $2 \%$ or about six times higher than the Mammalian value. 
The Gomez et al. study risks being misunderstood, and therefore misrepresented, so it is important to be clear about its interpretation. Humans emerged from an evolutionary lineage with a long history of higher than average levels of lethal violence towards members of the same species. Even so, Rousseauians, might step in to say that our species' figure of $2 \%$ tells us nothing about our innate tendencies, it might merely reflect a calculated or environmentally-induced response to the environments in which early humans lived.

Perhaps, but this objection falters when we appreciate that animals that live in particular kinds of environments over long periods of time tend to adapt to those environments genetically, and this makes some kinds of outcomes more likely than others: a wolf raised as a sheep will likely one day turn on its fellow sheep. So here, the authors' finding of a steady increase in violence throughout the many tens of thousands of years of the Mammalian tree is important - there was plenty of time for human ancestors to acquire and then bequeath to us genetic adaptations towards lethal violence. In this light, it is worth noting that our nearest living relatives, the chimpanzees (Pan troglodytes), with whom we share around $98 \%$ identify of our gene sequences, form packs to hunt down and kill stray males from other chimpanzee tribes ${ }^{5}$ and their hunting parties bear resemblances to human hunter-gatherer warfare ${ }^{6}$.

Others will object that it is difficult to derive reliable estimates of lethal violence. Anticipating this, the authors test for several biases including variation in sample sizes and sampling effort, and uncertainty about the phylogeny of mammals itself, showing that none of these qualitatively alters their results. The authors also find that species we expect to be violent, like the carnivores, are violent, and species we do not expect to be violent, like rabbits and whales, tend not to be. That, and they find that rates of violence are heritable in the Mammalian phylogeny.

Still, Rousseauians might have a corner to fight. The authors' estimates of lethal violence in humans vary widely over time, probably too quickly to be attributable to genetic changes. Their Palaeolithic samples ( 12 to $50 \mathrm{kya}$ ) have rates very close to the $2 \%$ predicted at the origin of our species, but then rates rise to as high as 15 to $30 \%$ (with high uncertainty) in samples from between 3000 and 500 years before the present, before declining in contemporary populations. The rise tends to correlate with moving from pre-societal (state of nature) to tribal and then organised political societies with a warrior class.

Where does this leave us? Social scientists take note: the Gomez et al. study, by opening up a new approach to uncovering the origins of human violence, gives good grounds for believing we are intrinsically more violent than the average mammal, and their findings fit well with anthropological accounts describing pre-state human societies as being engaged in 'constant battles' ${ }^{17,8}$. But societies can also modify our innate tendencies. Rates of homicide in modern societies ${ }^{9}$ with police forces, legal systems, jails and strong cultural mores that reject violence are, at less than 10 in 100,000 , or $0.01 \%$, about two-hundred times lower than Gomez et al. predict for our state of nature. Hobbes has landed a serious blow on Rousseau but not quite knocked him out.

Mark Pagel is in the School of Biological Sciences at the University of Reading, Reading RG6 6UR, UK. Email: m.pagel@reading.ac.uk

1. Hobbes, T. . Leviathan. Pelican Classics edition, London: Penguin Press (1651 [1968]).

2. Rousseau, J-J. The Social Contract. Ware, UK: Wordsworth editions (1762 [1998]).

3. Gomez, J.M., Verdu, M., Gonzalez-Megias, A., and Mendez, M. The phylogenetic roots of human lethal violence. Nature, X, XXX-XXX (2016). 
4. Harvey, P. H., \& Pagel, M. The comparative method in evolutionary biology (Vol. 239). Oxford: Oxford University press (1991).

5. Wilson, Michael L., et al. "Lethal aggression in Pan is better explained by adaptive strategies than human impacts." Nature 513, 414-417 (2014).

6. Wrangham, Richard W., and Luke Glowacki. "Intergroup aggression in chimpanzees and war in nomadic hunter-gatherers." Human Nature 23, 5-29 (2012).

7. Keeley, Lawrence H. War before civilization. New York: Oxford University Press (1996).

8. LeBlanc, Steven A., and K. E. Register. Constant Battles. New York: St. Martin's Press (2003).

9. United Nations Office on Drugs and Crime. 2011. Global study on homicide.

http://www.unodc.org/documents/data-and-

analysis/statistics/Homicide/Globa_study_on_homicide_2011_web.pdf

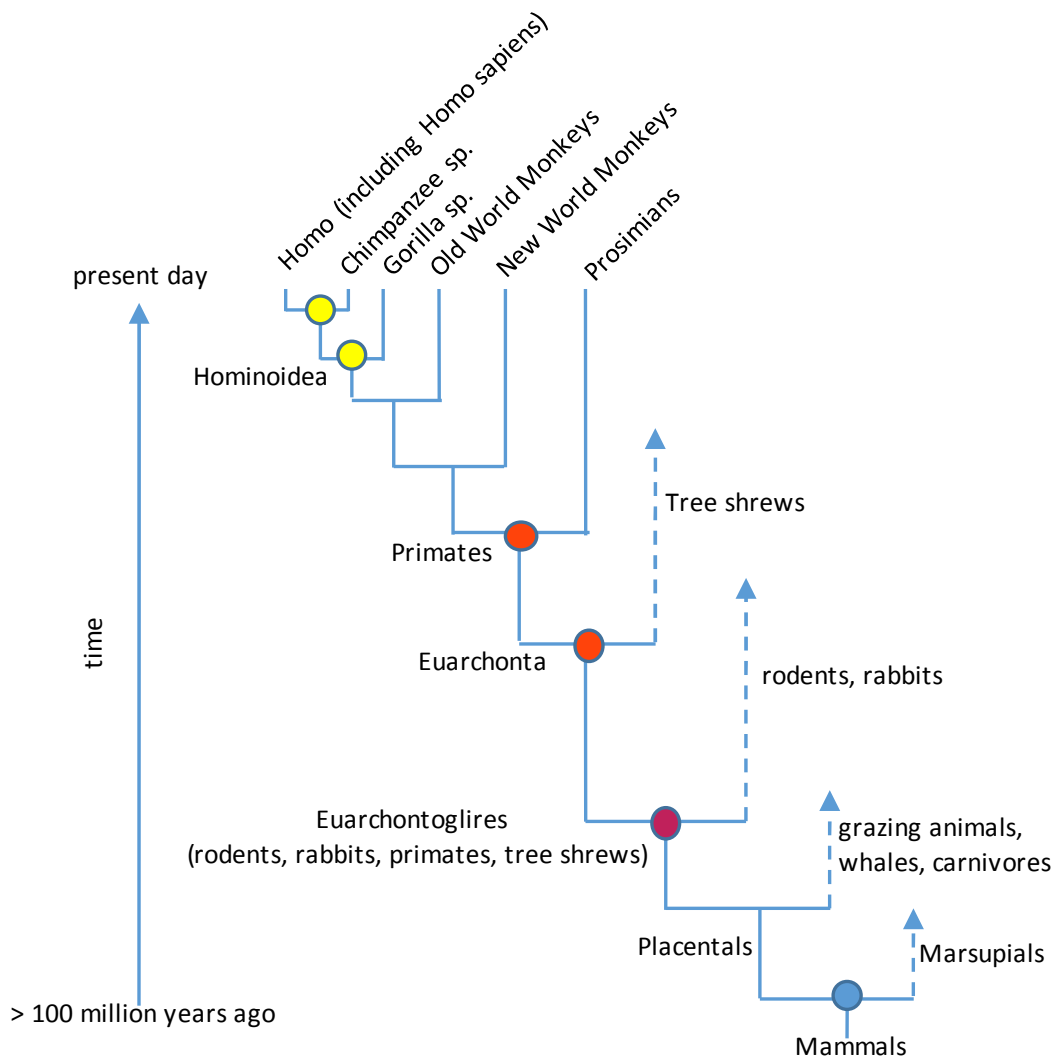

Figure. Schematic phylogenetic tree of the mammals showing major divisions and selected groups. Colour codes represent the rate of lethal violence from low (blue) to medium (maroon) and then high (yellow), taken from Gomez et al.

Times are not shown to scale. Dashed arrows extend to the present day. Species shown are not complete but representative of membership in their group. 